\title{
The role of limestone during fluidized bed oxy-combustion of coal and biomass
}

\author{
(1)

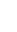

(1)

Abstract

The interest in bio-CCS technologies is growing due to their potential to reduce $\mathrm{CO}_{2}$ emission in power generation. Oxy-co-firing in fluidized-bed units is one of the available techniques to develop bio-CCS, offering wide fuel flexibility and low $\mathrm{SO}_{2}$ and $\mathrm{NO}_{\mathrm{x}}$ emissions. This paper discusses the results of an experimental campaign carried out in a lab-scale fluidized bed reactor. The work focuses on the influence of limestone when oxy-firing blends of lignite and corn stover. Two different types of limestone with two Ca:S molar ratios were tested, and operational conditions were selected to compare the mechanisms governing desulphurization. Emissions of $\mathrm{SO}_{2}, \mathrm{NO}$ and $\mathrm{HCl}$, together with deposition rates and ash mineralogy are studied in the paper. $\mathrm{SO}_{2}$ capture increases with the Ca:S ratio and bed temperature, but to a different extent depending on the limestone fragmentation. The amount of $\mathrm{NO}$ emitted rises with the Ca:S ratio and the presence of calcined limestone (indirect desulphurization). The $\mathrm{HCl}$ concentration in the gas phase is dominated by alkali sulfation. Finally, the conditions for the highest desulphurization efficiency diminished the deposition rates, but increased the risk for chlorine-induced corrosion.

\section{Keywords}

Oxy-combustion, Limestone, Emissions, Deposition, Biomass, Fluidized beds 8

\footnotetext{
${ }^{1}$ Corresponding author, e-mail address: luisig@unizar.es
} 


\section{Introduction}

Among the carbon capture and storage technologies (CCS), oxy-firing is one of the nearly commercially available solutions [1-3]. The investment during the last few years has allowed demonstration-scale facilities to be commissioned in which the feasibility of oxy-firing has been proved [4-7]. Nevertheless, important research efforts are still ongoing concerning its efficiency, emissions and fuel-related issues [8-12].

Oxy-combustion was initially developed and scaled-up in pulverized fuel units, but now oxy-fired fluidized bed boilers are of similar size. The latter offers the additional capability of burning low-rank fuels with good efficiency. This includes combustion of residual biomass, which implies $\mathrm{CO}_{2}$-neutral power generation [13-15]. Bio-CCS technologies based on the combination of residual biomass combustion and permanent $\mathrm{CO}_{2}$ removal are considered to be negative emission concepts [16-18].

Despite the use of residual biomass for power generation can result in environmental benefits related to $\mathrm{SO}_{2}$ and $\mathrm{NO}_{\mathrm{x}}$ emissions [19, 20], several operational issues arise related to its mineral matter composition. The release of alkali metals, which are mainly present in herbaceous biomasses, promotes condensation on water-tube surfaces, limiting the heat transfer efficiency. Additionally, alkali chlorides in deposits interact with $\mathrm{Fe}$ and $\mathrm{Cr}$, accelerating corrosion of heat exchangers in boilers [21-24]. In the case of fluidized bed units, interactions with silicates (in the sand) increase the risk of bed agglomeration. To reduce these difficulties, some researchers have explored the addition of alumina, dolomite, kaolin or limestone in the bed inventory [14].

The co-combustion of coal and residual biomass has been found to decrease agglomeration and corrosion risks compared to firing biomass alone [25-27]. The effectiveness of co-firing in preventing deposition of alkali chlorides is due to sulphur in coal since $\mathrm{SO}_{2}$ and $\mathrm{SO}_{3}$ react with alkali chlorides, yielding alkali sulphates (R.1, R.2):

$$
\begin{gathered}
2 \mathrm{MCl}+\mathrm{SO}_{2}+\mathrm{H}_{2} \mathrm{O}+1 / 2 \mathrm{O}_{2} \rightarrow \mathrm{M}_{2} \mathrm{SO}_{4}+2 \mathrm{HCl} \\
2 \mathrm{MCl}+\mathrm{SO}_{3}+\mathrm{H}_{2} \mathrm{O} \rightarrow \mathrm{M}_{2} \mathrm{SO}_{4}+2 \mathrm{HCl}
\end{gathered}
$$

These mechanisms reduce the interaction between the bed material and alkali metals, lessening the deposition of alkali chlorides [28]. The formation of alkali sulphates is not 
58 desirable from the point of view of heat transfer since fouling may be increased, but at least the risk of tube corrosion is reduced.

In fluidized bed reactors, $\mathrm{SO}_{2}$ and $\mathrm{SO}_{3}$ available for (R. 1) and (R. 2) are usually limited by in-situ desulphurization due to sorbent addition, generally limestone. Depending on the operational conditions, desulphurization can be carried out following two different mechanisms. When limestone is calcined, yielding $\mathrm{CaO}$ (R. 3), it retains $\mathrm{SO}_{2}$ following reaction (R. 4):

$$
\begin{gathered}
\mathrm{CaCO}_{3} \leftrightarrow \mathrm{CaO}+\mathrm{CO}_{2} \\
\mathrm{CaO}+\mathrm{SO}_{2}+1 / 2 \mathrm{SO}_{2} \rightarrow \mathrm{CaSO}_{4}
\end{gathered}
$$

This two-step mechanism, also called indirect capture, is typically found in atmospheric fluidized beds under conventional combustion. However, under oxy-firing conditions, with higher $\mathrm{CO}_{2}$ concentrations, calcination can be inhibited [29] and $\mathrm{SO}_{2}$ reacts with $\mathrm{CaCO}_{3}$ by means of a direct capture mechanism (R. 5):

$$
\mathrm{CaCO}_{3}+\mathrm{SO}_{2}+1 / 2 \mathrm{O}_{2} \rightarrow \mathrm{CaSO}_{4}+\mathrm{CO}_{2}
$$

At typical bed temperatures $\left(\sim 850{ }^{\circ} \mathrm{C}\right)$, direct capture is the governing mechanism for $\mathrm{SO}_{2}$ retention. Direct capture is slower than indirect desulphurization mainly due to the smaller pores of limestone compared to those of lime, so this process is controlled by the diffusion of $\mathrm{SO}_{2}$ in the particle and in the product layer [30]. Accordingly, other studies have found that indirect capture offers the highest desulphurization efficiencies also under oxy-firing conditions, but for an optimum temperature in the range of $900-925^{\circ} \mathrm{C}$ $[31,32]$.

On the other hand, some researchers have investigated the effect of co-firing in $\mathrm{O}_{2} / \mathrm{CO}_{2}$ atmospheres. Skeen et al. [33] studied the effect of co-firing sawdust and coal in a pulverized burner, reporting a sharp increase in emissions of $\mathrm{NO}$ with the $\mathrm{O}_{2}$ concentration in the primary oxidizer stream. Riaza et al. [34] added biomass to coal in an entrained-flow reactor to study ignition and NO emission. Moroń and Rybak [35] and Pickard et al. [36] reported a reduction of $\mathrm{NO}_{\mathrm{x}}$ and $\mathrm{SO}_{2}$ emissions during co-firing under $\mathrm{O}_{2} / \mathrm{CO}_{2}$ atmospheres. Jurado et al. [37] highlighted the relevance of increasing the concentration of corrosive substances due to recycled flue gases, while Ekvall et al. [38, 
39] injected $\mathrm{KCl}$ into a pulverized fuel reactor, obtaining a higher alkali sulfation in oxy-firing mode than in air-firing mode.

Nevertheless, there are few experiences to date concerning oxy-firing of coal and biomass in fluidized bed facilities. Tan et al. [40] conducted oxy-co-firing experiments to demonstrate the viability of this technology and characterize pollutant emission. Duan et al. [41] focused on $\mathrm{NO}_{\mathrm{x}}$ emission, observing dependencies similar to oxy-firing of coal alone. Kosowska-Golachowska et al. [42] studied the influence of the fluidizing gas composition in combustion, reducing burn-out time and increasing temperature with the highest $\mathrm{O}_{2}$ concentration.

There is a lack of research addressing oxy-firing of coal with residual biomass in fluidized bed reactors, and this paper aims to increase knowledge in this field. In particular, there are no reported works regarding the influences of limestone and the desulphurization mechanisms when coal and biomass are fired together. This paper describes and discusses the experimental results of oxy-firing campaign with lignite and corn stover, encompassing gaseous emissions, the ash composition and the characterization of deposits.

\section{Experimental setup}

\subsection{Experimental facility}

The experimental campaign was conducted in a $100 \mathrm{~kW}_{\text {th }}$ fluidized bed. Figure 1 shows an updated scheme of the plant after a recent refurbishment. The height of the reactor is $3500 \mathrm{~mm}$, and the inner diameter is $205 \mathrm{~mm}$. The unit can be operated under airfiring and oxy-firing modes, using $\mathrm{O}_{2} / \mathrm{CO}_{2}$ mixtures from commercial gas cylinders. The bed temperature is controlled by means of four water-cooled probes, whereas the freeboard is electrically heated to maintain the temperature. Fuels and sorbents are fed from hoppers by means of independent screw feeders.

The operational parameters are measured by thermocouples, pressure sensors and flowmeters and are continuously recorded. The flue-gas composition is provided on-line by a gas analyser. $\mathrm{CO}, \mathrm{CO}_{2}, \mathrm{SO}_{2}$ and $\mathrm{NO}$ concentrations are measured by NDIR (nondispersive infrared) sensors. A paramagnetic sensor is used to measure $\mathrm{O}_{2}$ 
concentration. The measurement uncertainties are 1\% for the temperature sensors, $2 \%$

116 for the pressure sensors and 1\% for the gas analyser cells.

117 To simulate deposition on the superheater tubes, an air-cooled probe can be inserted at 118800,2000 or $3300 \mathrm{~mm}$ over the distributor plate. A removable coupon made of AISI 119 Type 304 stainless steel is placed in the tip of the probe for further SEM-EDX analysis 120 of the deposits. The probe is equipped with a thermocouple and a PID controller, which 121 determines the air flow-rate required to maintain the prescribed surface temperature.

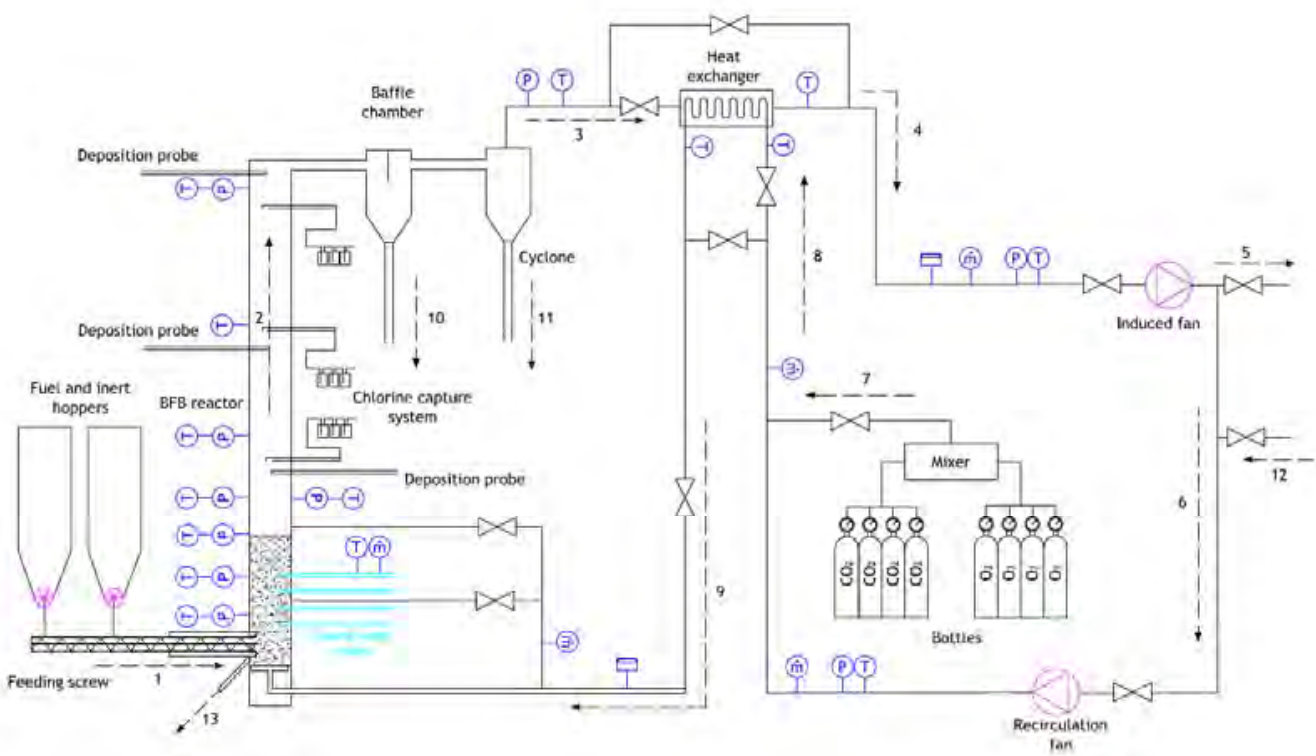

Solids feeding to the reactor Flue gas leaving the reactor Flue gas leaving the cyclone Cooled flue gas to bag filter Flue gas to the stack

Recycled flue gas
O2/CO2 mixtures from the bottles Cold oxidizer to heat exchanger Hot oxidizer to the reactor Ash from the baffle chamber Ash from the cyclone leg

Air inlet (when conventional firing) Bed ashes

127 Gas samples can be taken while on-load at 800, 2000 and $3100 \mathrm{~mm}$ over the distributor plate. Each sample is conveyed through three impingers with a $0.1 \mathrm{M}$

Figure 1. Oxy-fired fluidized bed facility. $\mathrm{Na}_{2} \mathrm{CO}_{3}$ solution that retains chlorides, fluorides, sulphates and nitrates. The chlorine concentration in the impinger solution is determined by ion chromatography. Solids can 
134 The coal selected for the experiments was Spanish lignite, which has a very high 135 sulphur and ash content (see Table 1). The mean particle size was $0.7 \mathrm{~mm}$, with particle 136 sizes between 0.3 and $1.0 \mathrm{~mm}$.

\begin{tabular}{|c|c|c|}
\hline & Lignite & Corn Stover \\
\hline \multicolumn{3}{|c|}{ Proximate analysis (\%wt.) } \\
\hline Moisture & 13.57 & 6.18 \\
\hline Ash & 30.30 & 5.50 \\
\hline Volatiles & 25.72 & 70.68 \\
\hline Fixed carbon & 30.41 & 17.64 \\
\hline \multicolumn{3}{|c|}{ Ultimate analysis (\%wt.) } \\
\hline $\mathbf{C}$ & 40.53 & 43.30 \\
\hline $\mathbf{H}$ & 3.18 & 5.82 \\
\hline $\mathbf{N}$ & 0.28 & 0.57 \\
\hline $\mathbf{S}$ & 6.65 & 0.11 \\
\hline Cl & - & 0.35 \\
\hline LHV (kJ/kg) & 14434 & 15438 \\
\hline \multicolumn{3}{|l|}{ Ash (\%wt.), by ICP } \\
\hline $\mathrm{Al}_{2} \mathrm{O}_{3}$ & 26.01 & 1.36 \\
\hline $\mathrm{CaO}$ & 3.27 & 8.72 \\
\hline $\mathrm{Fe}_{2} \mathrm{O}_{3}$ & 22.23 & 6.08 \\
\hline $\mathrm{K}_{2} \mathrm{O}$ & 0.92 & 27.90 \\
\hline MgO & 0.96 & 3.27 \\
\hline $\mathrm{Na}_{2} \mathrm{O}$ & 0.12 & 0.22 \\
\hline $\mathrm{SiO}_{2}$ & 41.06 & 29.81 \\
\hline $\mathrm{TiO}_{2}$ & 0.76 & 0.80 \\
\hline $\mathrm{P}_{2} \mathrm{O}_{5}$ & - & 3.81 \\
\hline $\mathrm{MnO}_{2}$ & - & 0.14 \\
\hline
\end{tabular}

Table 1. Fuel analysis, heating value and ash composition, as received.

139 Corn stover, with $0.35 \%$ chlorine content as received, was the herbaceous biomass 140 selected for the experiments. Aiming to test the influence of the chlorine content, the 141 corn stover was doped with a $\mathrm{KCl}$ solution to increase the concentration up to $1 \% \mathrm{Cl}$. 142 The apportioned $\mathrm{KCl}$ was dispersed onto the biomass surface as $1 \mu \mathrm{m}$ crystals identified 143 by SEM (Figure 2). For that particle size, it has been claimed that in-flight sulfation is 
144 achievable at the short gas residence times typical of combustion systems [43]. The 145 resulting biomass was ground and sieved to obtain a fraction between 1.0 and $2.0 \mathrm{~mm}$.

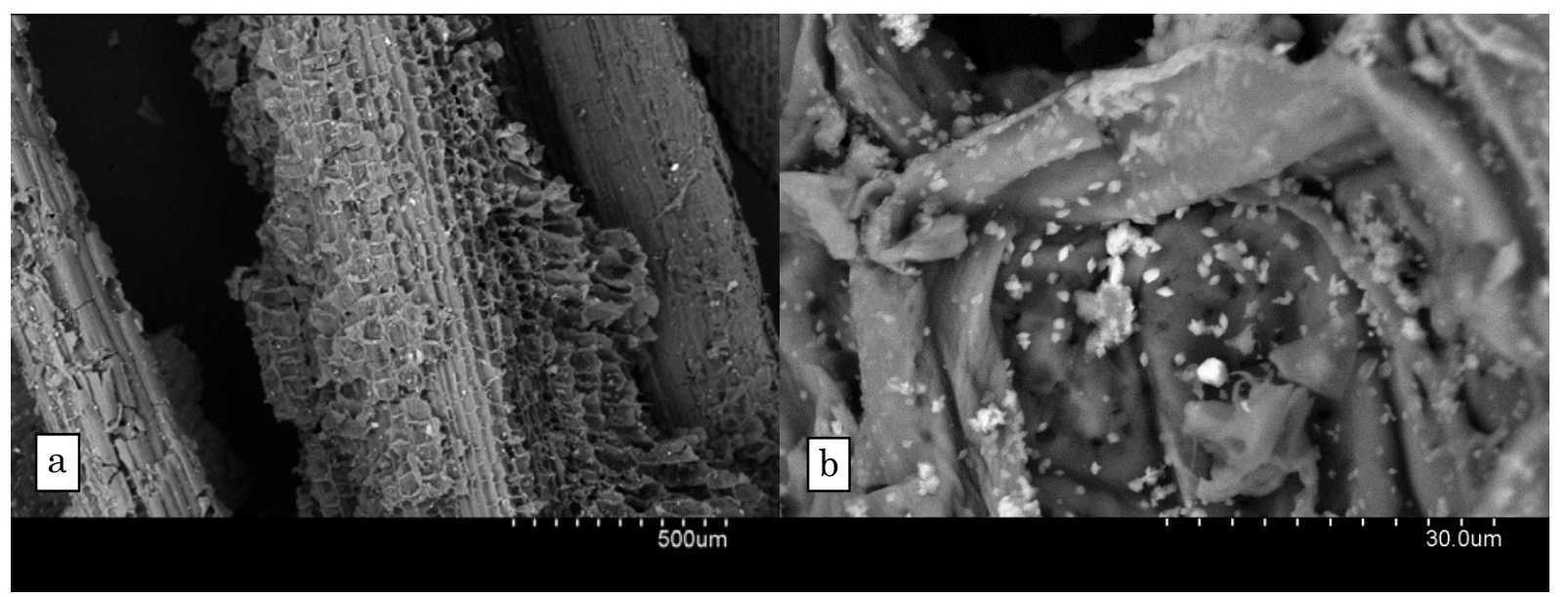

Figure 2. (a) SEM micrograph of $\mathrm{KCl}$ doped biomass, (b) detailed micrographs of surface $\mathrm{KCl}$ crystals.

As regards the sorbents, two domestic limestones with high $\mathrm{CaCO}_{3}$ contents (> 97\%) were selected: Granicarb limestone and Bahoto limestone. The mean particle size was approximately $0.6 \mathrm{~mm}$ for both. Silica sand was the inert constituent of the bed at the beginning of each test, with the same mean particle size.

\subsection{Experimental conditions}

A total set of six tests were conducted burning a blend of lignite and corn stover, with a coal/biomass ratio of $70 / 30 \%$ on an energy basis. Table 2 summarizes the experimental conditions during the tests.

The first test was run under air-firing conditions at a bed temperature of $850{ }^{\circ} \mathrm{C}$. The other five tests were run under oxy-firing conditions with a 35/65\% $\mathrm{O}_{2} / \mathrm{CO}_{2}$ mixture. To study the influence of the desulphurization mechanism during the oxy-firing tests, the bed temperature was modified from $850{ }^{\circ} \mathrm{C}$ (direct capture, non-calcining conditions) to $925^{\circ} \mathrm{C}$ (indirect capture, calcining conditions). A reference molar ratio of $\mathrm{Ca}: \mathrm{S}=6$ was adopted due to the high sulphur content of the coal and the execution of tests under non-calcining conditions (lower desulphurization efficiencies could be expected). The molar ratio was decreased to 2 for a single test to discuss its effect under calcining conditions. Four tests were conducted with Granicarb limestone, the rest with Bahoto limestone. 
169 In the present paper, the experiments are named according to the experimental 170 conditions: first, the combustion mode is noted as air-firing $(\mathrm{A})$ or oxy-firing $(\mathrm{O})$; second, 171 the limestone type is indicated as Granicarb (G) or Bahoto (B); third, the Ca:S molar 172 ratio is either 2 or 6; and finally, the desulphurization mechanism is either indirect (I) 173 or direct (D). During all of the experiments, the deposition probe and chlorine capture 174 system were inserted into the highest ports at the top of the freeboard. The deposition 175 probe temperature was set at $450{ }^{\circ} \mathrm{C}$.

176

\begin{tabular}{lccccc}
\hline Test \# & Fluidizing gas & Limestone & Ca:S & $\begin{array}{c}\text { Bed } \\
\text { temperature }\end{array}$ & $\begin{array}{c}\text { Desulphurization } \\
\text { mechanism }\end{array}$ \\
\hline A-G6I & Air & Granicarb & 6 & $850{ }^{\circ} \mathrm{C}$ & Calcining \\
O-G6D & $35 / 65 \% \mathrm{O}_{2} / \mathrm{CO}_{2}$ & Granicarb & 6 & $850{ }^{\circ} \mathrm{C}$ & Non-calcining \\
O-G6I & $35 / 65 \% \mathrm{O}_{2} / \mathrm{CO}_{2}$ & Granicarb & 6 & $925{ }^{\circ} \mathrm{C}$ & Calcining \\
O-G2I & $35 / 65 \% \mathrm{O}_{2} / \mathrm{CO}_{2}$ & Granicarb & 2 & $925{ }^{\circ} \mathrm{C}$ & Calcining \\
O-B6D & $35 / 65 \% \mathrm{O}_{2} / \mathrm{CO}_{2}$ & Bahoto & 6 & $850{ }^{\circ} \mathrm{C}$ & Non-calcining \\
O-B6I & $35 / 65 \% \mathrm{O}_{2} / \mathrm{CO}_{2}$ & Bahoto & 6 & $925{ }^{\circ} \mathrm{C}$ & Calcining \\
\hline
\end{tabular}

Table 2. Experimental conditions during the tests.

178

179

180

181

182

183

184

185

186

187

188

189

190

191

192

\subsection{Experimental techniques}

Solid samples were studied by means of scanning electron microscopy in a Hitachi S$3400 \mathrm{~N}$ device, in which micrographs of selected surfaces were taken by a retrodispersive electron detector for morphology characterization. The chemical composition of selected surfaces and mapping were performed by means of EDX in a Rontec XFlash detector. X-ray diffraction (XRD) was used to determine the phase composition of the crystalline species in a Siemens Bruker D8 Advance diffractometer set for CuKa radiation. The diffraction angle scanned was $20-60^{\circ}(2 \theta)$ using a step size of $0.05^{\circ}(2 \theta)$.

\section{Results and discussion}

\subsection{Emissions}

Table 3 shows the mean values and standard deviations for the freeboard temperature and flue gas concentrations recorded on-line during the tests (the concentrations were 
193 normalized to $6 \% \mathrm{O}_{2}$ ). The table also includes the calculated desulphurization efficiency 194 and $\mathrm{HCl}$ concentration in the freeboard.

\begin{tabular}{|c|c|c|c|c|c|c|}
\hline & A-G6I & O-G6D & O-G6I & O-G2I & O-B6D & O-B6I \\
\hline $\mathrm{T}_{\mathrm{fb}}\left({ }^{\circ} \mathrm{C}\right)$ & $793 \pm 10$ & $791 \pm 9$ & $700 \pm 17$ & $721 \pm 8$ & $794 \pm 10$ & $798 \pm 8$ \\
\hline $\mathrm{O}_{2}(\%)$ & $7.53 \pm 0.55$ & $7.72 \pm 0.38$ & $7.93 \pm 0.75$ & $7.87 \pm 1.30$ & $7.62 \pm 0.81$ & $12.72 \pm 1.97$ \\
\hline $\mathrm{CO}\left(\mathrm{mg} / \mathrm{Nm}^{3}\right)$ & $386 \pm 28$ & $209 \pm 10$ & $189 \pm 16$ & $186 \pm 29$ & $380 \pm 40$ & $43 \pm 10$ \\
\hline NO (mg/Nm³) & $149 \pm 19$ & $399 \pm 58$ & $530 \pm 69$ & $412 \pm 58$ & $348 \pm 57$ & $510 \pm 42$ \\
\hline $\mathrm{SO}_{2}\left(\mathrm{mg} / \mathrm{Nm}^{3}\right)$ & $331 \pm 32$ & $13950 \pm 745$ & $3151 \pm 345$ & $8187 \pm 910$ & $2181 \pm 351$ & $824 \pm 72$ \\
\hline NO (mg/MJ) & 27.7 & 39.9 & 54.1 & 39.6 & 35.9 & 49.1 \\
\hline $\mathrm{SO}_{2}(\mathrm{mg} / \mathrm{MJ})$ & 66 & 1488 & 354 & 843 & 246 & 86 \\
\hline Eff. Desulph (\%) & 97.9 & 54.1 & 89.1 & 74.0 & 92.4 & 97.4 \\
\hline $\mathrm{HCl}\left(\mathrm{mg} / \mathrm{Nm}^{3}\right)$ & 67 & 243 & 155 & 211 & 116 & 85 \\
\hline
\end{tabular}

196 197
Table 3. Freeboard temperature; $\mathrm{CO}, \mathrm{NO}$ and $\mathrm{SO}_{2}$ emissions (normalized to $6 \% \mathrm{O}_{2}$ ); desulphurization efficiency; and $\mathrm{HCl}$ concentration.

\subsection{1. $\mathrm{SO}_{2}$ emissions}

The experimental campaign with Granicarb limestone confirms the expected results. The desulphurization efficiency obtained from the test under conventional combustion (A-G6I) reached a value of almost 98\%; this is explained by the calcining conditions and bed temperature being within the optimum range for $\mathrm{SO}_{2}$ capture [44].

The change to the direct desulphurization mechanism in test $\mathrm{O}-\mathrm{G} 6 \mathrm{D}$, as a consequence of the high $\mathrm{CO}_{2}$ concentration, yielded an important increase of emitted $\mathrm{SO}_{2}$ and a consequent drop of the desulphurization efficiency to 54\%. This observation is consistent with the results found by de Diego et al. [31, 45] and Wu et al. [46]. These researchers reported lower efficiencies as a consequence of the lower porosity of the non-calcined sorbent (for typical particle sizes in fluidized beds).

Oxy-fired tests O-G2I and O-G6I were carried out again under calcining conditions since the bed temperature was increased to $925^{\circ} \mathrm{C}$ (see also Table 2), leading to an important increase in the desulphurization efficiency in comparison to the O-G6D tests, even in the case of decreasing the molar ratio of $\mathrm{Ca}: \mathrm{S}$ to 2 . A similar behaviour was found by Jia et al. [47] during the operation of an oxy-fired CFB plant at high temperature. 
215 If test A-G6I is compared to O-G6I, the desulphurization efficiency is almost 8 points 216 lower in the case of oxy-firing. An explanation for this reduction was given by Valverde 217 and co-workers [48]. They determined that the pores formed under oxy-firing conditions 218 during calcination were smaller due both to the higher temperatures and $\mathrm{CO}_{2}$ 219 concentrations.

220 The use of Bahoto limestone in the last two tests resulted in an increase of the 221 desulphurization efficiency to over 90\%. Again, the efficiency is better when operating 222 under calcining conditions. If test $\mathrm{O}-\mathrm{G} 6 \mathrm{D}$ is compared to test $\mathrm{O}-\mathrm{B} 6 \mathrm{D}$, the increase in 223 efficiency is quite outstanding, i.e., from 54.1\% to $92.4 \%$. This behaviour is mainly 224 related to the severe fragmentation suffered by the Bahoto limestone, according to the 225 samples taken in the circuit hoppers. The amount of solids collected after the Bahoto 226 test was five times higher than that after the Granicarb test, pointing out a significant 227 increase in the elutriation rates (despite the fluidization velocity remaining the same). 228 These fragmentation conditions were also confirmed by particle micrographs, as shown 229 in the following section. Since the molar ratio Ca:S is sufficiently high, higher limestone 230 fragmentation means a larger surface available to capture $\mathrm{SO}_{2}$.

232 The lowest NO emission was detected for the air-fired test, A-G6I. If compared to the 233 corresponding test using oxy-firing, O-G6I, emissions are doubled (in normalized units, $234 \mathrm{mg} / \mathrm{MJ}$, to avoid the effect of the atmosphere). This is not only an effect of the $\mathrm{O}_{2}$ 235 concentration but also of the lower CO level for the O-G6I test.

The increase in emissions from O-G6D $\left(399 \mathrm{mg} / \mathrm{Nm}^{3}\right)$ to $\mathrm{O}-\mathrm{G} 6 \mathrm{I}\left(530 \mathrm{mg} / \mathrm{Nm}^{3}\right)$ is 237 explained by the presence of calcined limestone rather than the temperature. Despite 238 the increase in temperature that promotes calcining conditions, the effect is attenuated 239 since the freeboard temperature was kept at a lower value (see Table 3). For similar 240 mean temperatures, the difference in emissions was then mainly caused by calcined 241 limestone, with almost the same $\mathrm{O}_{2}$ and $\mathrm{CO}$ concentrations for both tests. This effect 242 has also been observed for conventional coal combustion (i.e., calcining conditions). De 243 Diego et al. [49] reported that NO emission doubled after the addition of limestone in a 244 fluidized bed. Ziljma et al. [50-52] found an important increase of NO due to calcined 245 limestone; the increase progressively slowed down as $\mathrm{CaSO}_{4}$ was formed. Liu and Gibbs 
246 [53] studied how limestone affected the emitted NO in the case of char combustion. On 247 the other hand, Hansen et al. [54] and Lupiáñez et al. [55] showed the limited catalytic 248 effect of fresh limestone in comparison to calcined limestone.

249 The same result is obtained when Bahoto limestone is supplied (test O-B6D vs. O-B6I), 250 but to an even larger extent. This is also due to the higher $\mathrm{O}_{2}$ excess and lower $\mathrm{CO}$ 251 concentration during the last test.

\subsection{3. $\mathrm{HCl}$ in gas phase}

253 The $\mathrm{HCl}$ concentration in the gas phase was estimated from the gas samples taken at 254 the top of the freeboard and retained in the impingers. $\mathrm{HCl}$ is an indicator of alkali 255 sulfation, see reactions (R. 1) and (R. 2). This can be relevant when firing high-sulphur 256 coal together with high-chlorine biomass. According to the results shown in Table 3, the 257 trend is clear: the higher the $\mathrm{SO}_{2}$ concentration in the flue gases, the higher the $\mathrm{HCl}$ 258 concentration detected (due to the enhancement of the sulfation of alkali chlorides). 259 This trend is shown in Figure 3, which clearly shows the relationship. In consequence, 260 in-bed desulphurization determines the release of $\mathrm{HCl}$. The larger amount of chlorine in 261 the gas phase is expected to reduce the presence of chlorine in the deposits as 262 condensed alkali chlorides.

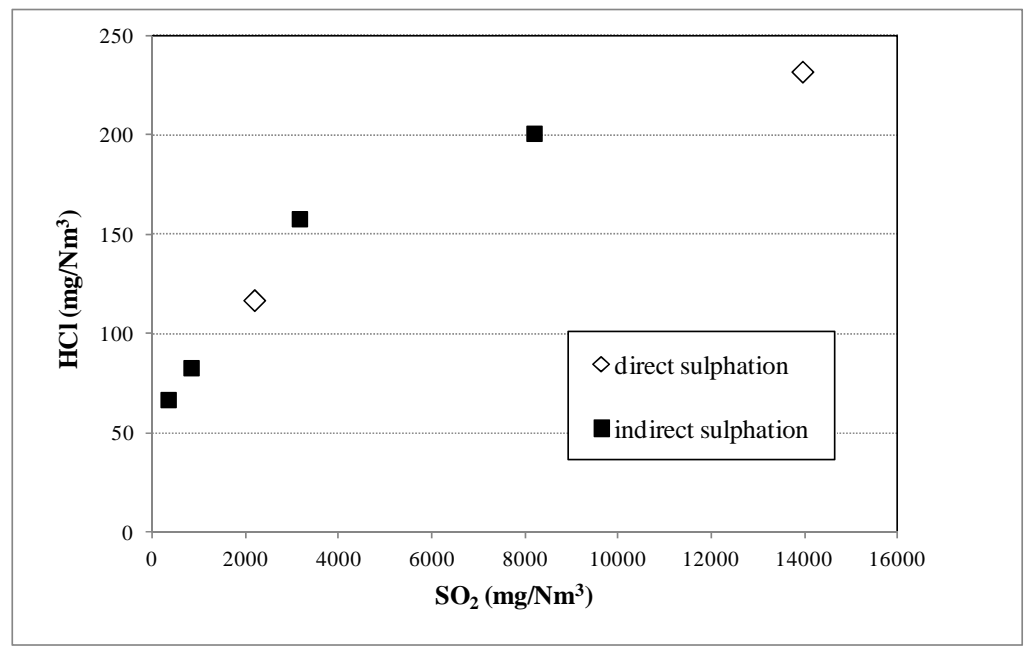

Figure 3. Correlation between $\mathrm{HCl}$ and $\mathrm{SO}_{2}$ in the gas-phase.

Aside from sulfation, $\mathrm{HCl}$ can also be released by alkali silication or aluminosilication 269 [25, 56], according to reactions (R. 6) and (R. 7): 


$$
\begin{gathered}
2 \mathrm{MCl}+\mathrm{nSiO}_{2}+\mathrm{H}_{2} \mathrm{O} \rightarrow \mathrm{M}_{2} \mathrm{O} \cdot \mathrm{n \textrm {SiO } _ { 2 }}+2 \mathrm{HCl} \\
2 \mathrm{MCl}+\left(\mathrm{nSiO}_{2}+\mathrm{Al}_{2} \mathrm{O}_{3}\right)+\mathrm{H}_{2} \mathrm{O} \rightarrow 2 \mathrm{MAlSi}_{n / 2} \mathrm{O}_{(n+2)}+2 \mathrm{HCl}
\end{gathered}
$$

271

272 The extent of this mechanism is discussed in the following section when the 273 characterization of ash and deposits is addressed.

274 In brief and regarding emissions in general, the type of limestone used has been 275 revealed to have a large effect on the control of pollutants $\left(\mathrm{SO}_{2}, \mathrm{NO}_{\mathrm{x}}\right)$. In comparison to 276 air, shifting to an $\mathrm{O}_{2} / \mathrm{CO}_{2}$ atmosphere was found to increase emissions. Regarding the 277 control of $\mathrm{SO}_{2}$, the $\mathrm{O}_{2} / \mathrm{CO}_{2}$ effect can be balanced by increasing the molar ratio of Ca:S 278 or the temperature, but then, $\mathrm{NO}_{\mathrm{x}}$ formation can be catalysed if free lime is available. 279 At that point, non-calcining operation can be recommended to jointly control $\mathrm{SO}_{2}$ and $280 \mathrm{NO}_{\mathrm{x}}$ in oxy-fired units since desulphurization efficiencies over $90 \%$ can be achieved, as 281 our work shows.

282 The selection of the limestone must also take into account its fragmentation propensity, 283 since it is a very influential factor on emissions. Future industrial developments will 284 face a trade-off: the larger the fragmentation rate, the higher the $\mathrm{SO}_{2}$ capture 285 capability, but the greater the issues related to elutriation, erosion and fouling. The 286 addition of an herbaceous biomass at a limited ratio contributes to reducing pollutants, 287 but its impact on fouling/corrosion must also be assessed.

\subsection{Ash composition}

\subsubsection{Bottom ash}

The bottom solids are mainly composed of the initial silica sand, partially sulphated sorbent particles and fuel ash. Visual inspection confirmed that none of the experiments presented agglomerated particles, despite the $30 \%$ of corn stover in the blend and high temperature $\left(925^{\circ} \mathrm{C}\right)$ during some experiments. The presence of calcite and some refractory elements from lignite ash contributes to the avoidance of agglomeration [27]. The incidence of coating formation was demonstrated by the surface SEM-EDX of the bottom solids. Figure 4 is a micrograph of a representative sand-bed particle, the surface composition of which, also shown in the Figure, indicates the attachment of 
298 submicron-sized particles, mainly calcium-based fines and $\mathrm{Al}$ and $\mathrm{Fe}$ from the coal 299 mineral matter, which does not involve a risk of agglomeration.

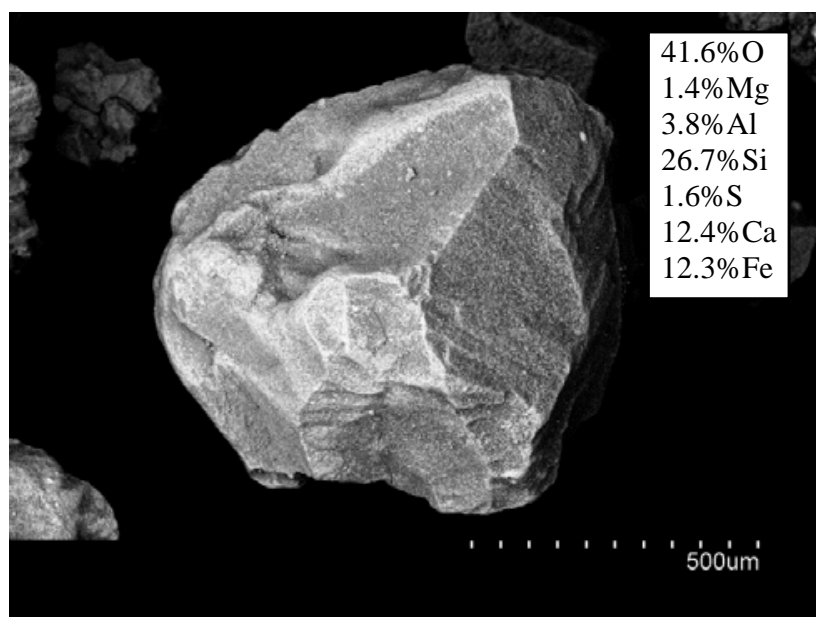

Figure 4. SEM surface micrographs of a sand particle (test O-B6D) and the EDX composition.

Table 4 shows the composition determined by SEM-EDX of fuel ash particles (which are identified by the similar silicon-to-aluminium ratio than in the original ash). Tests with direct sulfation present higher percentages of surface Ca than tests in which limestone is initially calcined and are higher in the case of Bahoto limestone due to its greater degree of fragmentation. This fact could be an indication that submicron $\mathrm{CaCO}_{3}$ is more prone to attach to bed particles than $\mathrm{CaO}$. The formation of coating layers hinders the study of other surface reactions, such as potassium silication (R. 6) and aluminosilication (R. 7), compared to the surface K/Al ratios [57]. For this reason, in the present work, the surface $\mathrm{K} / \mathrm{Al}$ ratios, on an atomic basis, were only calculated for tests under calcining conditions, showing lower surface calcium (see Table 4). The values obtained (0.21-0.27) note the incidence of potassium retention by aluminosilication on ash particles to a similar extent and irrespective of the desulphurization efficiency.

\begin{tabular}{c|ccccccc|c}
\multicolumn{1}{c}{} & $\mathbf{M g}$ & $\mathbf{A l}$ & $\mathbf{S i}$ & $\mathbf{S}$ & $\mathbf{K}$ & $\mathbf{C a}$ & $\mathbf{F e}$ & $\mathbf{K} / \mathbf{A l}$ \\
\hline O-G6D & 1.95 & 24.44 & 30.5 & 5.62 & 5.77 & 16.78 & 14.94 & - \\
O-G6I & 2.62 & 27.17 & 29.83 & 0.00 & 10.70 & 8.00 & 21.59 & 0.27 \\
O-G2I & 2.66 & 16.90 & 17.89 & 1.11 & 6.29 & 8.64 & 46.51 & 0.25 \\
O-B6D & 3.66 & 14.99 & 16.60 & 3.27 & 1.08 & 30.00 & 30.38 & - \\
O-B6I & 2.09 & 23.34 & 26.01 & 2.29 & 7.10 & 9.83 & 29.34 & 0.21 \\
\hline
\end{tabular}

Table 4. EDX surface elemental composition (\%wt.) of bottom solids and the $\mathrm{K} / \mathrm{Al}$ ratio. 
317 Potassium penetration was studied by EDX and q-mapping of $\mathrm{K}$ in cross sections (see 318 Figure 5). The micrograph images of fuel ash after tests A-G6I (Figure 5.a) and O-B6D 319 (Figure 5.b) show the morphology of the ash particles, with cracks, voids and pores 320 related to the original coal texture and its evolution with combustion. Bright iron 321 clusters from inherent pyrite and well-defined quartz crystals are also seen along the cross section. The potassium q-maps are overlapped onto selected areas. They indicate the presence of potassium in the external core of particles, which confirms the reaction of $\mathrm{KCl}$ with reactive $\mathrm{Si}$ and $\mathrm{Al}$ oxides on the ash surfaces, following (R. 6) and (R. 7). The penetration of $\mathrm{K}$ is studied by the EDX composition of a number of spots along the particles.

Figure 5.c shows the relative percentage of potassium $\mathrm{K} /(\mathrm{Al}+\mathrm{Si}+\mathrm{K}+\mathrm{Ca}+\mathrm{Fe})$ related to the depth of penetration. Potassium can be found in the external $50 \mu \mathrm{m}$ of the ash particles in both tests performed at $850^{\circ} \mathrm{C}$, with a clear relationship with the ash texture, and to a similar extent for the different combustion conditions (air vs. oxyfiring or indirect sulfation vs. direct).
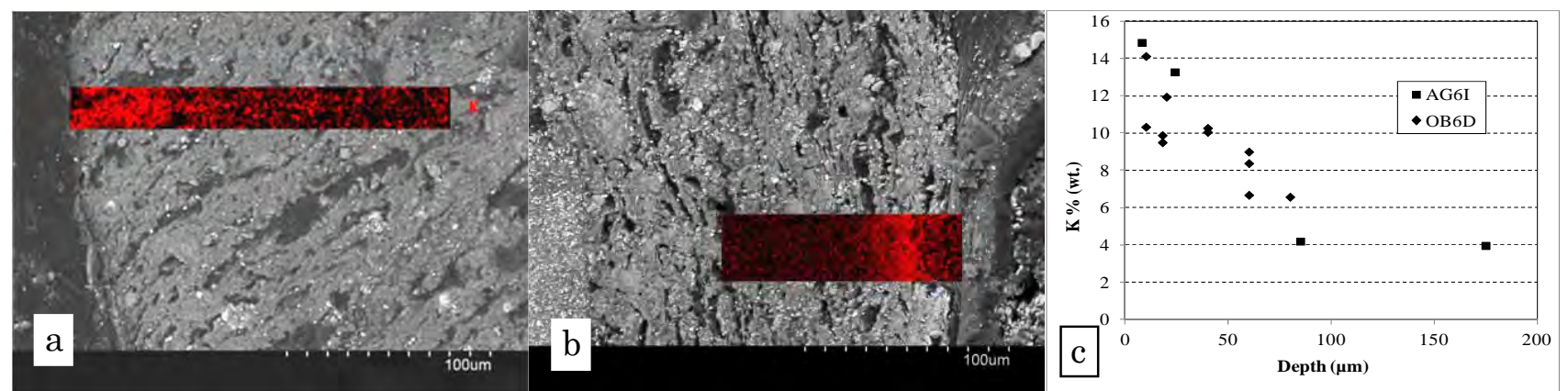

Sorbent particles were also studied by SEM-EDX. The Granicarb sorbent presents a dense and compact morphology after combustion (Figure 6.a). Line-scanning, elemental mapping and EDX of the sample shown in Figure 6.b were used to demonstrate that

Figure 5. Q-map of samples from tests A-G6I (a) and O-B6D (b), and the relative K content (c). sulfation followed an unreacted core model, leading to pore plugging [58]. On the contrary, the Bahoto limestone structure is more porous and presents a high degree of fracture, as presented in Figure 6.c, showing a network sulfation mode [59] for those particles remaining in the bed. 


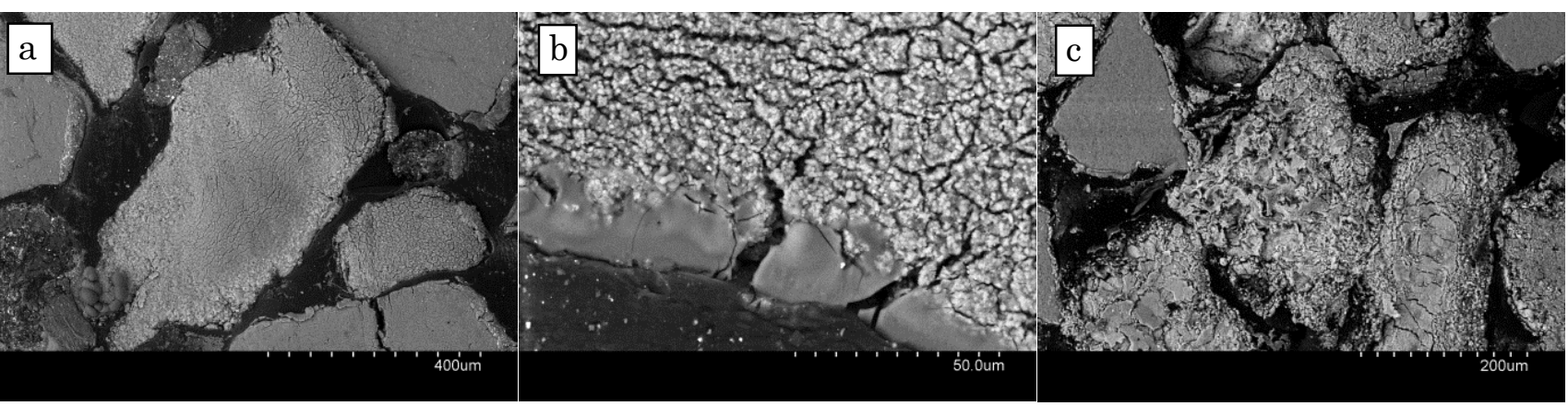

Figure 6. Granicarb sorbent in the bottom bed after test A-6GI (a) and a detailed micrograph of its surface (b); Bahoto sorbent in bottom bed after test O-6BD (c).

Aside from the desulphurization mechanism and its effect on the characterization of sorbent particles, no relevant influence of the type of limestone has been found for bottom ash.

The chemical characterization of sorbent particles also indicated the absence of chlorine. Chlorination of limestone (R.8) or lime (R.9) could be expected due to the presence of $\mathrm{HCl}$ in the gas-phase [60]:

$$
\begin{gathered}
\mathrm{CaCO}_{3}+2 \mathrm{HCl} \leftrightarrow \mathrm{CaCl}_{2}+\mathrm{H}_{2} \mathrm{O}+\mathrm{CO}_{2} \\
\mathrm{CaO}+2 \mathrm{HCl} \leftrightarrow \mathrm{CaCl}_{2}+\mathrm{H}_{2} \mathrm{O}
\end{gathered}
$$

Nevertheless, sulfation of lime or limestone (R.4 and R.5) is favoured in simultaneous presence of $\mathrm{SO}_{2}$ and $\mathrm{HCl}$ in the gas-phase at $850^{\circ} \mathrm{C}$ [61], reducing the extent of calcium chlorination. This also limits the agglomeration risk caused by the interaction of chlorine with the bed materials.

\subsubsection{Fly ash}

The samples obtained in the cyclone for each test were studied by EDX. The elemental surface composition (excluding $\mathrm{C}$ and $\mathrm{O}$ ) of the powders is shown in Table 5 for tests with $\mathrm{Ca}: \mathrm{S}=6$. The occurrence of $\mathrm{Al}, \mathrm{Si}$ and $\mathrm{Fe}$ denotes the presence of fuel ash. The amount of calcium in A-G6I and O-B6I samples is high. This could be an indication of sorbent elutriation. Apportioning of the Ca species in the cyclone solids was performed by XRD (Figure 7). 


\begin{tabular}{c|cccccccc} 
& $\mathbf{M g}$ & $\mathbf{A l}$ & $\mathbf{S i}$ & $\mathbf{S}$ & $\mathbf{K}$ & $\mathbf{C l}$ & $\mathbf{C a}$ & $\mathbf{F e}$ \\
\hline A-G6I & 1.35 & 5.68 & 8.88 & 7.10 & 1.78 & 1.08 & 57.53 & 16.56 \\
O-G6D & 2.35 & 20.00 & 31.61 & 6.60 & 1.13 & 0.00 & 15.50 & 22.80 \\
O-G6I & 0.00 & 12.94 & 30.55 & 6.62 & 2.62 & 0.00 & 16.92 & 30.34 \\
O-B6D & 1.54 & 13.70 & 23.28 & 4.85 & 1.22 & 0.00 & 19.89 & 35.52 \\
O-B6I & 1.95 & 5.72 & 10.74 & 10.06 & 1.89 & 0.00 & 56.20 & 13.44 \\
\hline
\end{tabular}

Table 5. EDX surface elemental composition (\%wt.) of cyclone solids.
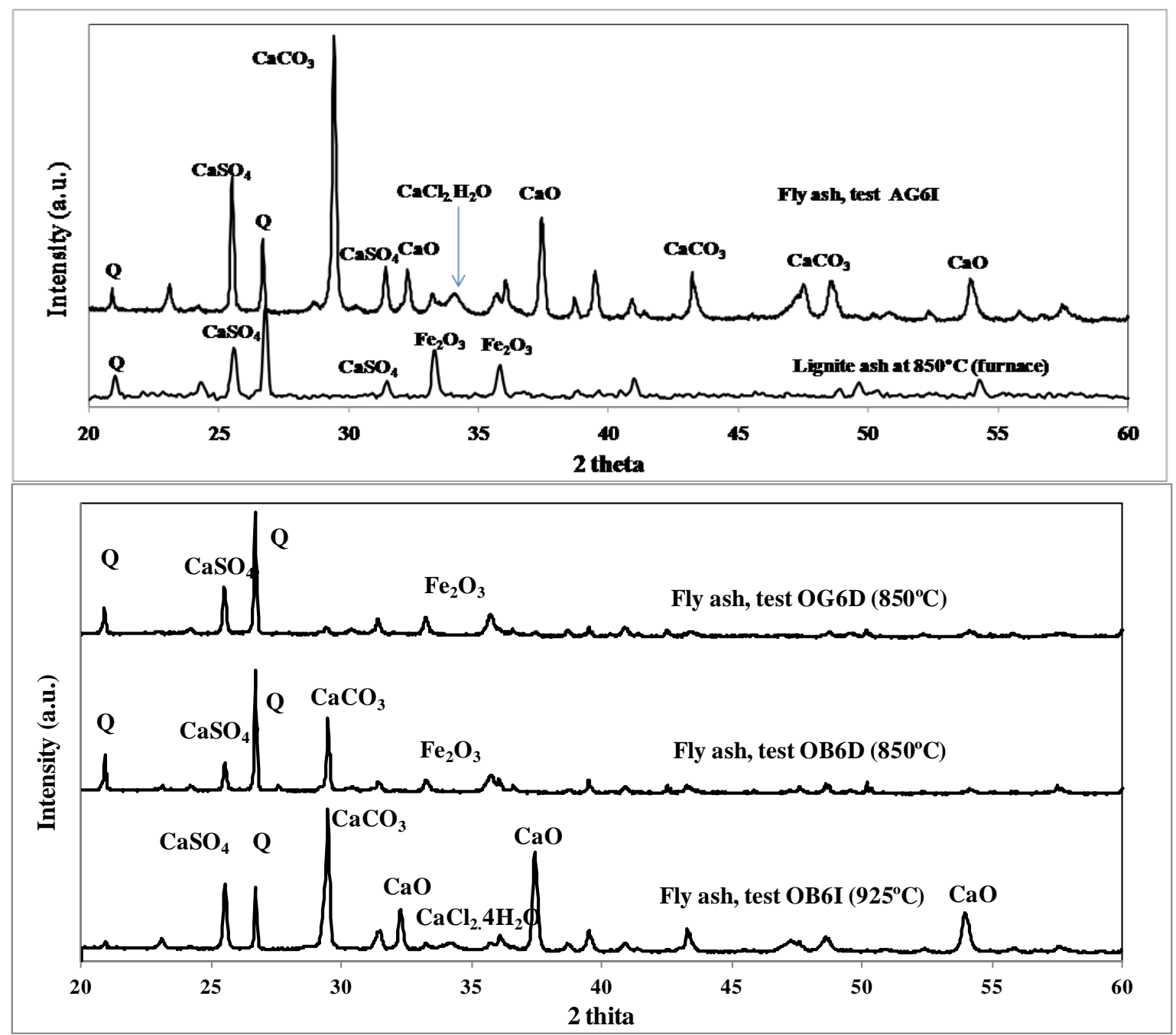

Figure 7. XRD composition of cyclone solids from tests A-G6I, O-G6D, O-B6D and O-B6I.

375 Sulphated sorbent $\left(\mathrm{CaSO}_{4}\right)$ and fuel ash (quartz and hematite) are present in all 376 samples. It is worth mentioning that the quartz peak is compatible with evolution with 
the temperature of the original mineral matter in coal. In Figure 7, it is possible to see that the XRD of lignite coal ash obtained in a muffle furnace (in air, at $850{ }^{\circ} \mathrm{C}$ ) gives a major peak for quartz, whereas the initial aluminosilicate is not detected and hematite peaks are observed as oxidation products from the original pyrite.

The presence of unreacted limestone is clear in both the Bahoto tests and also for O$\mathrm{B} 6 \mathrm{I}$, which is evidence that sorbent fragmentation occurs prior to calcination. $\mathrm{CaO}$ is present for those cases carried out under indirect sulfation conditions (A-G6I and O-B6I tests), along with a small $\mathrm{CaCl}_{2} \cdot 4 \mathrm{H}_{2} \mathrm{O}$ peak, indicating partial chlorination of lime after reaction (R. 8) in $\mathrm{SO}_{2}$-depleted flue gas. EDX detected the presence of chlorine in A-G6I fly ash, but chlorine is under the detection limit in O-B6I fly ash (see Table 5). This fact is indicating that chlorination of lime is favoured at $600{ }^{\circ} \mathrm{C}$ in air combustion whereas it is limited in oxy-combustion due to competition with recarbonation of the available reactive calcium [62].

\subsection{Deposition}

Figure 8 shows the deposition coupons obtained after the six experiments. The coupons were analysed by SEM-EDX, as received.

The morphology of the deposits could be observed by SEM (Figure 9). The elemental composition of selected $20 \mu \mathrm{m} \times 20 \mu \mathrm{m}$ surface areas was obtained by EDX. Deposits consisted of condensed particles in the micron range, together with particles of ash and bed material. Compositions excluding elements $\mathrm{C}, \mathrm{O}$ and $\mathrm{Fe}$ are given in Table 6.

EDX revealed that the main elements present are $\mathrm{Ca}, \mathrm{K}$ and $\mathrm{S}$, whereas chlorine was only detected in the A-G6I and O-B6I deposits. This is consistent with the lowest $\mathrm{HCl}$ concentrations in the gas-phase detected for those tests, which were related to the highest desulphurization efficiencies (over 97\%).

Apportioning to the different salts cannot be performed according to the elemental composition, so for those cases in which deposits could be removed from the coupon, XRD characterization was performed, as shown in Figure 10. XRD confirmed the presence of both $\mathrm{KCl}$ and $\mathrm{CaCl}_{2}$ in the deposition coupon of $\mathrm{A}-\mathrm{G} 6 \mathrm{I}$, which was not found for tests O-G6I, O-G2I and O-B6D (as expected according to Table 6). Coupons from the test performed with Bahoto limestone showed an important presence of $\mathrm{CaCO}_{3}$ due to 
407 fragmentation. $\mathrm{CaSO}_{4}$ from sulfation was present in all coupons, as well as potassium 408 sulphate- identified as $\mathrm{K}_{3} \mathrm{H}\left(\mathrm{SO}_{4}\right)_{2}$.

409

410

411
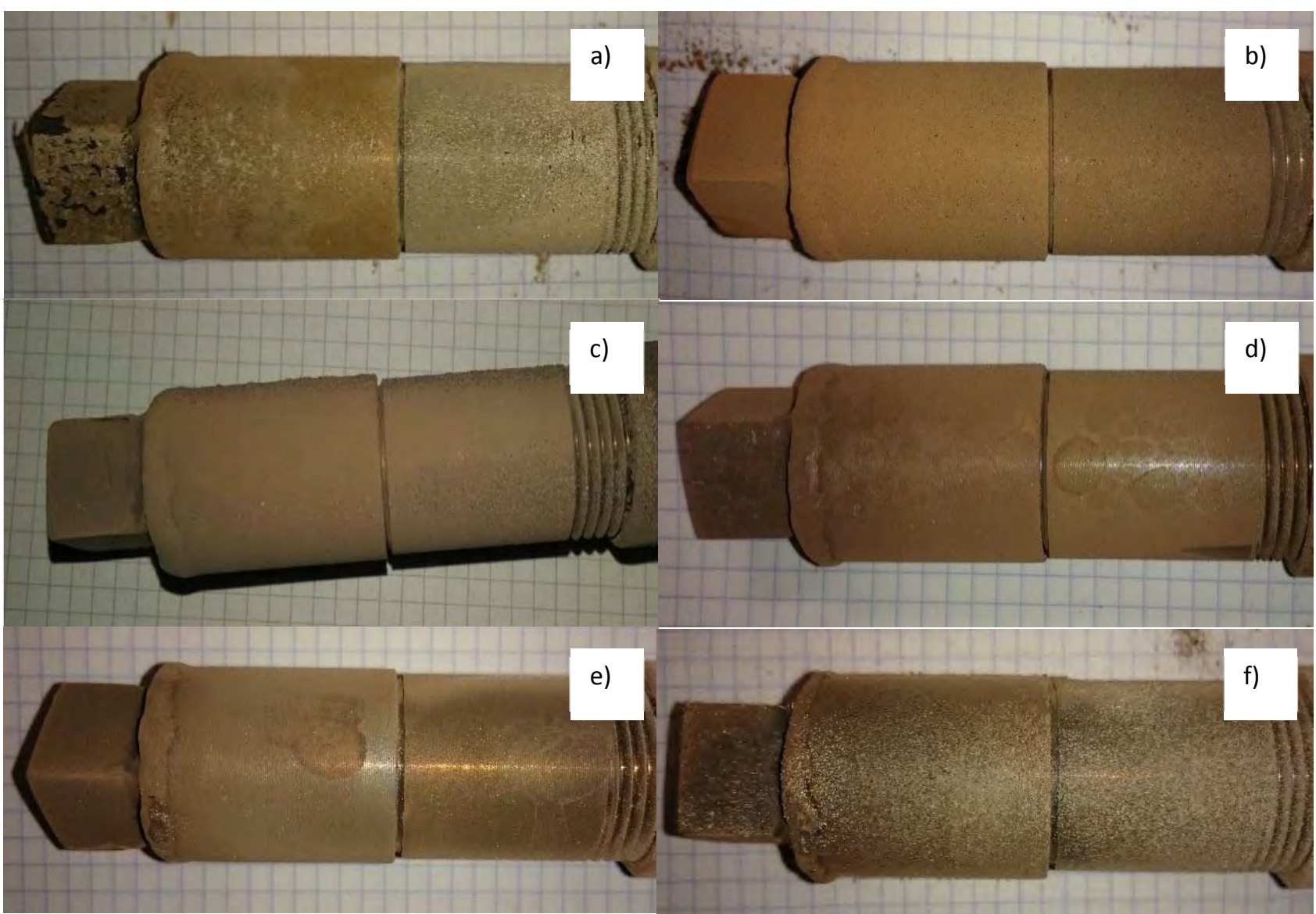

Figure 8. Deposition probes after tests: a) A-G6I, (b) O-G6D, (c) O-G6I, (d) O-G2I, (e) O-B6D, (f) O-B6I.

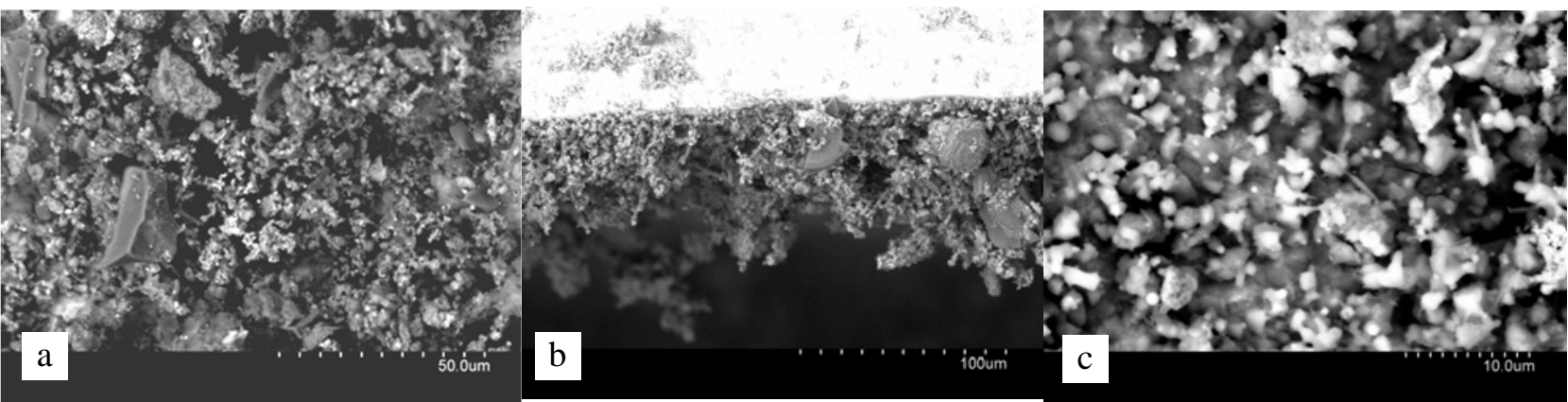

Figure 9. SEM micrographs of deposits from tests: (a) O-G6D, (b) O-G6I, (c) O-6BI. 


\begin{tabular}{c|cccccccc}
\multicolumn{1}{l}{} & Na & Mg & Al & Si & S & K & Cl & Ca \\
\hline A-G6I & 0.00 & 1.78 & 5.19 & 10.89 & 12.40 & 8.42 & 12.97 & 48.36 \\
O-G6D & 0.00 & 1.58 & 15.89 & 20.74 & 22.42 & 4.72 & 0.00 & 34.64 \\
O-G6I & 0.00 & 0.92 & 7.12 & 11.31 & 22.56 & 12.69 & 0.00 & 41.20 \\
O-G2I & 0.00 & 1.96 & 9.21 & 12.42 & 27.57 & 29.63 & 0.00 & 19.67 \\
O-B6D & 0.00 & 0.00 & 12.21 & 16.25 & 21.19 & 33.53 & 0.00 & 16.82 \\
O-B6I & 0.64 & 1.06 & 4.13 & 4.23 & 18.73 & 38.35 & 15.07 & 17.83 \\
\hline
\end{tabular}

Table 6. EDX surface elemental composition (\%wt.) of deposits.

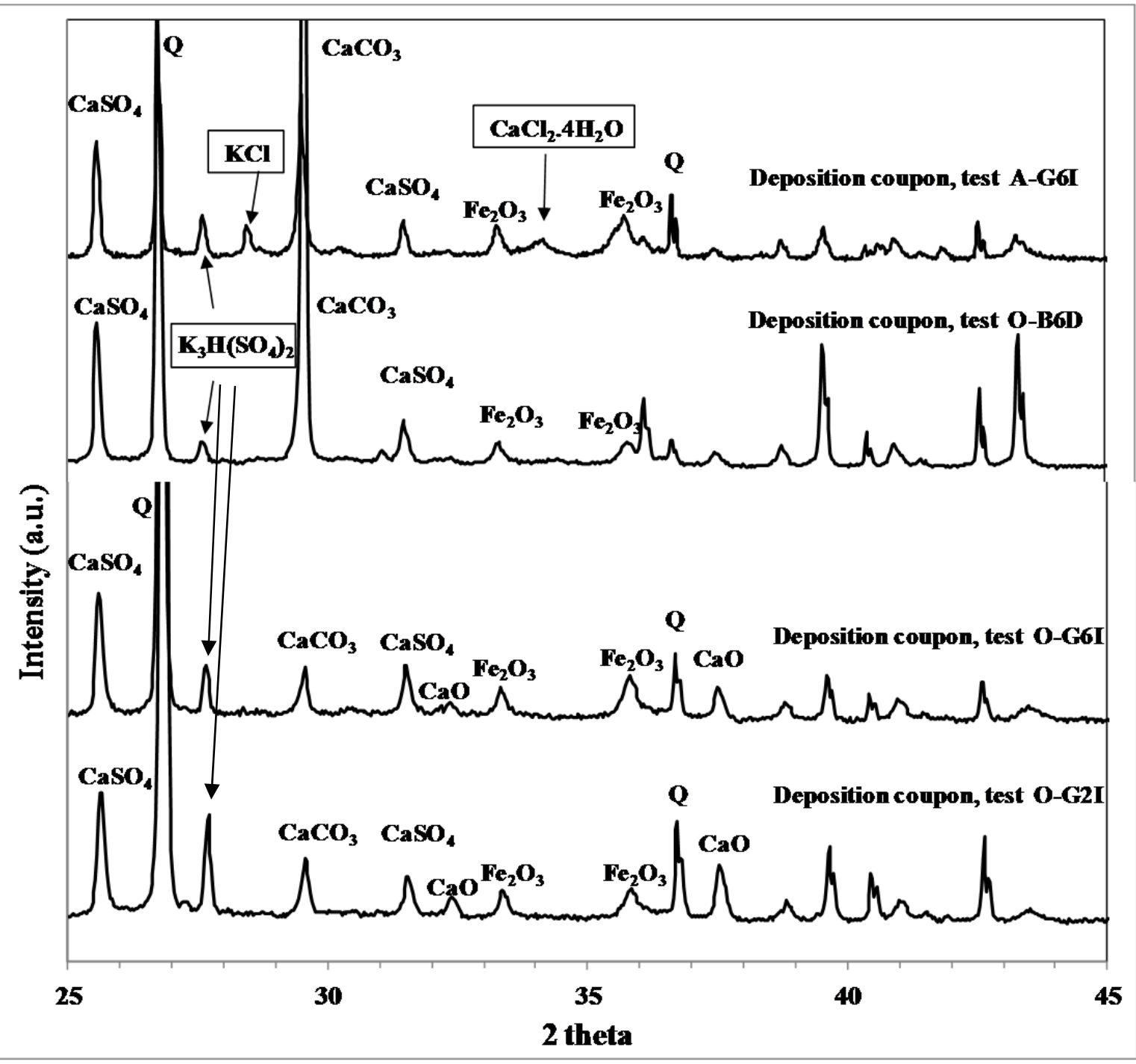

Figure 10. XRD composition of deposits formed during tests A-G6I, O-G6I, O-G2I and O-B6D. 
428 Summing sections 3.2 and 3.3, it is concluded that oxy-firing barely affects the 429 deposition rates in comparison to air-firing. Some increase of potassium sulphates in 430 the deposits is observed for most of the oxy-firing tests, which can promote fouling after 431 long-term operation. Nevertheless, and as a rule of thumb, no major operational 432 problems are expected under oxy-combustion in comparison to the wide experience 433 already available for air-fired operation of fluidized beds.

434 The composition of the deposits is fully consistent with the observed concentrations of $435 \mathrm{SO}_{2}$ and $\mathrm{HCl}$ in the gas phase. The limestone type indirectly influences the composition 436 of the deposits through the $\mathrm{SO}_{2}$ concentration (largely determined by the limestone 437 behaviour, as already discussed in section 3.1).

438 No influence of limestone has been observed on the composition of bed and fly ash. Lime 439 chlorination - a positive side-effect - was found to a limited extent, but only for those 440 tests with the higher deposition rates. Finally, agglomeration issues did not arise 441 during the entire test campaign irrespective of the limestone used. Despite the addition 442 of corn stover, and even for the higher temperature tests, operation of the fluidized-bed 443 reactor is proven to be feasible for the blend of risky fuels selected.

\subsection{Corrosion}

445 Oxidation scales were only detected in experiments A-G6I and O-B6I. In the air case, removing the deposits by gentle brushing involved the collection of oxidation scales, as studied by SEM-EDX (Figure 11.a). The oxidation scale comprises a dual layer of $\mathrm{Cr}_{2} \mathrm{O}_{3}$ $\mathrm{Fe}_{2} \mathrm{O}_{3}$, which is expected from the high chromium content in AISI 304 stainless steel. 449 The micrograph also shows the deposited material on the scale. Figure 11.b shows the condensed aerosols in the submicron range, the detailed composition of which by EDX is 451 described in Figure 11.c. The aerosols are rich in $\mathrm{Cl}$ (16.1\% atomic basis), K (13.5\%), Ca 452 (12.7\%) and S (6.4\%), with the rest composed of oxygen, which indicates the nucleation 453 and condensation of a mixture of $\mathrm{KCl}, \mathrm{CaCl}_{2}$, and $\mathrm{K}-\mathrm{Ca}$ sulphates. It has been stated 454 that, in contrast to $\mathrm{KCl}, \mathrm{CaCl}_{2}$ is only slightly corrosive to $\mathrm{SS} 304$ under similar 455 conditions [63]. 

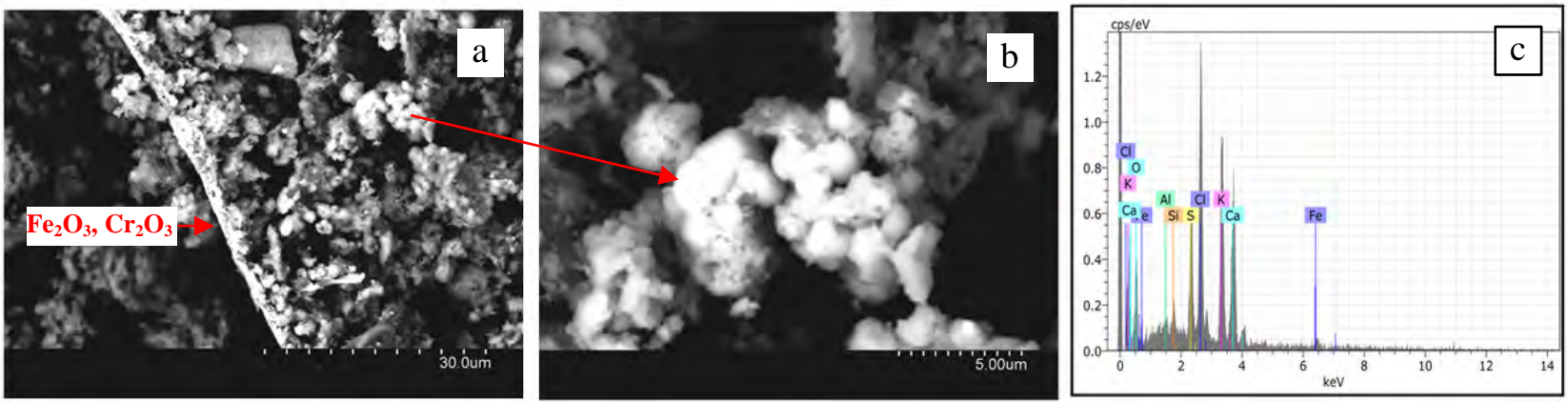

Figure 11. Deposit material from test A-6GI: (a) perpendicular view of the scale and deposit onto it; (b) details of the condensed aerosol cluster; (c) EDX composition of (b).

In the case of the $\mathrm{O}-6 \mathrm{BI}$ coupon, the fine deposit layer was washed off and the metallic surface was shown to be severely damaged by oxidation (Figure 12.a). SEM-EDX showed the spalled surface and, underneath, the formation of iron oxides that were rich in iron (Figure 12.b), which confirms the spallation of $\mathrm{Fe}_{2} \mathrm{O}_{3}-\mathrm{Cr}_{2} \mathrm{O}_{3}$ external scales and the formation of oxides, such as hematite, close to the metallic surface. These results demonstrate the incidence of accelerated corrosion due to the presence of $\mathrm{KCl}$ in deposits from the two tests with the highest degree of sulphur retention.

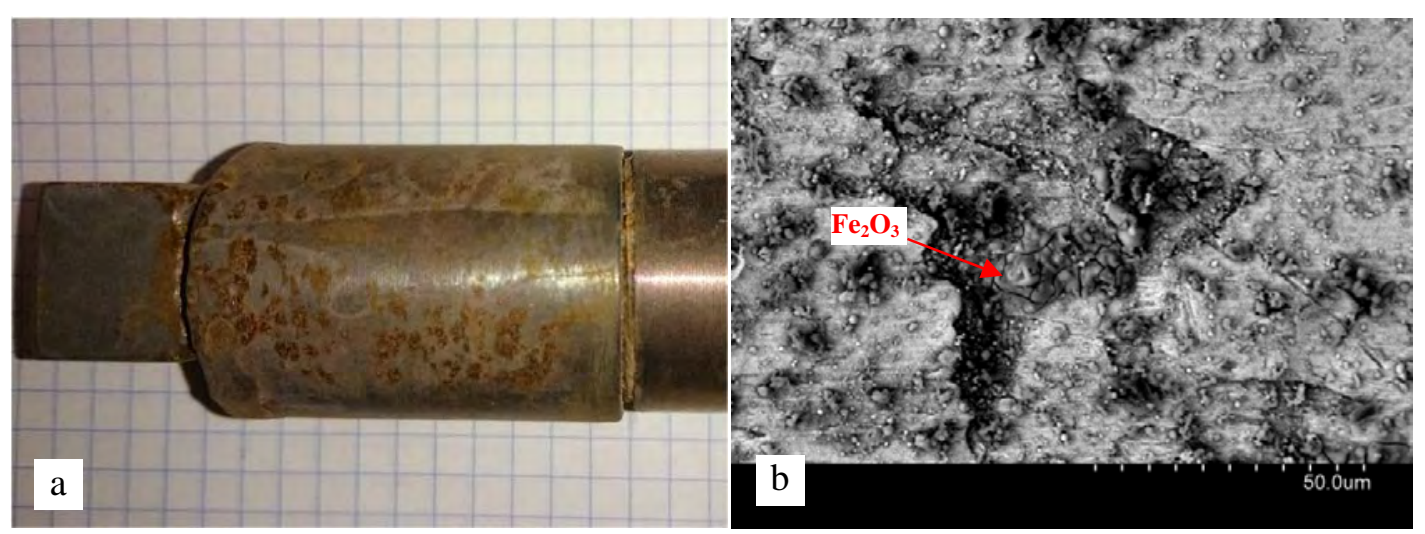

Figure 12. a) Washed deposition probe from test O-B6I; (b) and a detailed SEM micrograph.

In summary, oxy-firing is proven to alleviate corrosion issues compared to air operation. Only the test with the highest limestone fragmentation under calcining conditions yields a situation comparable to that observed for air. The results found in this work show the inter-relation between the type of limestone (determining the $\mathrm{SO}_{2}$ concentration, and depending on the desulphurization mechanism) and mineral matter of coal and biomass (involving the alkali chlorides) under different, realistic operating 
478 oxy-firing conditions. Again, non-calcining conditions are preferable, provided that a 479 large enough Ca:S ratio is used to achieve a high desulphurization efficiency.

\section{4. Conclusions}

481 The influence of the type of limestone and desulphurization mechanism on emissions, 482 ash composition, deposition and corrosion were discussed after an experimental 483 campaign carried out under lab-scale fluidized bed oxy-firing conditions, feeding a blend 484 of lignite and corn stover.

$485 \mathrm{SO}_{2}$ capture is better under calcining conditions than under non-calcining ones, but the 486 limestone type also has an outstanding relevance depending on the fragmentation 487 behaviour. Operation under calcining conditions requires higher bed temperatures under oxy-firing, so there is a risk of agglomeration when supplying biomass in the blend. However, no agglomeration was found for any of the tested conditions.

By contrast, $\mathrm{NO}_{\mathrm{x}}$ emissions are increased under calcining conditions due to the catalytic effect of free lime. This can be problematic for enriched $\mathrm{O}_{2}$ atmospheres and when supplying biomass with a nitrogen content higher than that of coal. Hence, a compromise has to be adopted to jointly control the amounts of $\mathrm{SO}_{2}$ and $\mathrm{NO}_{\mathrm{x}}$ emitted.

Higher desulphurization efficiencies also promote the presence of chlorine in the deposits, thus the risk of corrosion. This was detected for the air- and oxy-fired tests, with efficiencies over $97 \%$, but with more severe damage after the air-fired test.

497 Alkali sulfation was found for the tests with higher $\mathrm{SO}_{2}$ contents, in agreement with the 498 $\mathrm{HCl}$ concentration in the gas phase, while alkali aluminosilication was shown to be almost the same, irrespective of the atmosphere or operating conditions. Condensation of potassium sulphates promotes deposition and increases fouling rates. Instead, the

\section{2} risk of chlorine-induced corrosion is reduced.

503 detected for the tests under calcining conditions, while limestone chlorination was not 504 found for the non-calcining tests. 


\section{Acknowledgements}

508 The work described in this paper was partially funded by the R+D Spanish National 509 Program from the Spanish Ministry of Economy and Competitiveness, under the Project 510 ENE2012-39114. The project is also co-funded by the European Commission (European 511 Regional Development Funds).

\section{References}

514 [1] Stanger R, Wall T, Spörl R, Paneru M, Grathwohl S, Weidmann M, et al. Oxyfuel

[2] Scheffknecht G, Makhadmeh LA, Schnell U, Maier J. Oxy-fuel coal combustiona review of the current state-of-the-art. Int J Greenhouse Gas Con 2011;5S:16-35.

[3] Singh RI, Kumar R. Current status and experimental investigation of oxy-fired fluidized bed. Renew. Sustain. Energy Rev. 2016; 61: 398-420.

[4] Lupion M, Diego R, Loubeau L, Navarrete B. CIUDEN CCS Project: Status of the $\mathrm{CO}_{2}$ capture technology development plant in power generation. Energy Procedia 2011;4:5639-46.

[5] Anheden M, Burchhardt U, Ecke H, Faber R, Jidinger O, Giering R, et al. Overview of operational experience and results from test activities in Vattenfall's $30 \mathrm{MW}_{\text {th }}$ oxyfuel pilot plant in Schwarze Pumpe. Energy Procedia 2011;4:941-50.

[6] Uchida T, Goto T, Yamada T, Kiga T, Spero C. Oxyfuel Combustion as $\mathrm{CO}_{2}$ Capture Technology Advancing for Practical Use - Callide Oxyfuel Project. Energy Procedia 2013;37:1471-9.

[7] Luo W, Wang Q, Liu Z, Zheng C. Dynamic simulation and exergy analysis for mode switching process in a $35 \mathrm{MW}_{\text {th }}$ oxyfuel pilot plant. $5^{\text {th }}$ Oxy-fuel Combust. Res. Netw. Meet., Wuhan (China): 2015.

[8] Bu CS, Gomez-Barea A, Chen XP, Leckner B, Liu DY, Pallares D, Lu P. Effect of $\mathrm{CO}_{2}$ on oxy-fuel combustion of coal-char particles in a fluidized bed: Modeling and comparison with the conventional mode of combustion. Appl Energy 2016; 177:247-259.

[9] Yin CG, Yan JY. Oxy-fuel combustion of pulverized fuels: Combustion 
fundamentals and modeling. Appl Energy 2016; 162: 742-762.

[10] Li SY, Xu MX, Jia LF, Tan L, Lu QG. Influence of operating parameters on $\mathrm{N}_{2} \mathrm{O}$ emission in $\mathrm{O}_{2} / \mathrm{CO}_{2}$ combustion with high oxygen concentration in circulating fluidized bed. Appl Energy 2016; 173: 197-209

[11] Oboirien BO, Thulari V, North BC. Enrichment of trace elements in bottom ash from coal oxy-combustion: Effect of coal types. Appl Energy 2016; 177: 81-86

[12] de Diego LF, de las Obras-Loscertales M, Rufas A, Garcia-Labiano F, Gayan P, Abad A, Adanez J. Pollutant emissions in a bubbling fluidized bed combustor working in oxy-fuel operating conditions: Effect of flue gas recirculation. Appl Energy 2013;102: 860-867

[13] Vicente ED, Tarelho LAC, Teixeira ER, Duarte M, Nunes T, Colombi C, et al. Emissions from the combustion of eucalypt and pine chips in a fluidized bed reactor. J Environ Sci 2016;42:246-58.

[14] Khan AA, de Jong W, Jansens PJ, Spliethoff H. Biomass combustion in fluidized bed boilers: Potential problems and remedies. Fuel Process Technol 2009;90:2150 .

[15] Davidsson KO, Åmand L-E, Elled A-L, Leckner B. Effect of cofiring coal and biofuel with sewage sludge on alkali problems in a circulating fluidized bed boiler. Energy \& Fuels 2007;21:3180-8.

[16] Pickard S, Daood SS, Nimmo W, Lord R, Pourkashanian M. Bio-CCS: co-firing of established greenfield and novel, brownfield biomass resources under air, oxygenenriched air and oxy-fuel conditions. Energy Procedia 2013;37:6062-9.

[17] Schakel W, Meerman H, Talaei A, Ramírez A, Faaij A. Comparative life cycle assessment of biomass co-firing plants with carbon capture and storage. Appl Energy 2014;131:441-67.

[18] Gładysz P, Ziębik A. Environmental analysis of bio-CCS in an integrated oxy-fuel combustion power plant with $\mathrm{CO}_{2}$ transport and storage. Biomass and Bioenergy 2016;85:109-18.

[19] Agbor E, Zhang X, Kumar A. A review of biomass co-firing in North America. Renewable and Sustainable Energy Reviews 2014; 40:930-943

[20] Sami M, Annamalai K, Wooldridge M. Co-firing of coal and biomass fuel blends. Progress in Energy and Combustion Science 2001; 27:171-214 
570

[21] Valmari T, Lind TM, Kauppinen EI, Sfiris G, Nilsson K, Maenhaut W. Field study on ash behavior during circulating fluidized-bed combustion of biomass. 2. Ash deposition and alkali vapor condensation. Energy \& Fuels 1999;13:390-5.

[22] Sandberg J, Karlsson C, Fdhila RB. A 7-year long measurement period investigating the correlation of corrosion, deposit and fuel in a biomass fired circulated fluidized bed boiler. Appl Energy 2011;88:99-110.

[23] Olivas-Ogaz MA, Paz MD, Liske J, Jonsson T. The effect of startup procedure of probe exposures on deposit and corrosion formation in a waste fired CFB boiler. 22 $2^{\text {nd }}$ Fluid. Bed Convers., Turku (Finland): 2015.

[24] Niu SL, Han KH, Lu CM. Characteristic of coal combustion in oxygen/carbon dioxide atmosphere and nitric oxide release during this process. Energy Convers Manag 2011;52:532-7.

[25] Aho M, Ferrer E. Importance of coal ash composition in protecting the boiler against chlorine deposition during combustion of chlorine-rich biomass. Fuel 2005;84:201-12.

[26] Akram M, Tan CK, Garwood DR, Fisher M, Gent DR, Kaye WG. Co-firing of pressed sugar beet pulp with coal in a laboratory-scale fluidised bed combustor. Appl Energy 2015;139:1-8.

[27] Barišić V, Peltola K, Coda Zabetta E. Role of pulverized coal ash against agglomeration, fouling, and corrosion in circulating fluidized-bed boilers firing challenging biomass. Energy \& Fuels 2013;27:5706-13.

[28] Shao Y, Xu C, Zhu J, Preto F, Wang J, Tourigny G, et al. Ash and chlorine deposition during co-combustion of lignite and a chlorine-rich Canadian peat in a fluidized bed - Effects of blending ratio, moisture content and sulfur addition. Fuel 2012;95:25-34.

[29] de Diego LF, de las Obras-Loscertales M, García-Labiano F, Rufas A, Abad A, Gayán P, et al. Characterization of a limestone in a batch fluidized bed reactor for sulfur retention under oxy-fuel operating conditions. Int J Greenh Gas Control 2011;5:1190-8.

[30] Liu H, Katagiri S, Kaneko U, Okazaki K. Sulfation behavior of limestone under high $\mathrm{CO}_{2}$ concentration in $\mathrm{O}_{2} / \mathrm{CO}_{2}$ coal combustion. Fuel 2000;79:945-53.

[31] de Diego LF, Rufas A, García-Labiano F, de las Obras-Loscertales M, Abad A, 
Gayán P, et al. Optimum temperature for sulphur retention in fluidised beds working under oxy-fuel combustion conditions. Fuel 2013;114:106-13.

[32] Díez LI, Lupiáñez C, Guedea I, Bolea I, Romeo LM. Anthracite oxy-combustion characteristics in a $90 \mathrm{~kW}_{\text {th }}$ fluidized bed reactor. Fuel Process Technol 2015;139:196-203.

[33] Skeen SA, Kumfer BM, Axelbaum RL. Nitric Oxide Emissions during Coal and Coal/Biomass Combustion under Air-Fired and Oxy-fuel Conditions. Energy \& Fuels 2010;24:4144-52.

[34] Riaza J, Gil MV, Álvarez L, Pevida C, Pis JJ, Rubiera F. Oxy-fuel combustion of coal and biomass blends. Energy 2012;41:429-35.

[35] Moron W, Rybak W. $\mathrm{NO}_{\mathrm{x}}$ and $\mathrm{SO}_{2}$ emissions of coals, biomass and their blends under different oxy-fuel atmospheres. Atmos Environ 2015;116:65-71.

[36] Pickard SC, Daood SS, Pourkashanian M, Nimmo W. Co-firing coal with biomass in oxygen- and carbon dioxide-enriched atmospheres for CCS applications. Fuel 2014;137:185-92.

[37] Jurado N, Darabkhani HG, Anthony EJ, Oakey JE. Oxy-combustion Studies Into the Co -Firing of Coal and Biomass Blends: Effects on Heat Transfer, Gas and Ash Compositions. Energy Procedia 2014;63:440-52.

[38] Ekvall T. Alkali sulphation in flames. $5^{\text {th }}$ Meeting IEAGHG Int. Oxyfuel Combustion Res. Netw., Wuhan (China): 2015.

[39] Ekvall T, Normann F, Andersson K, Johnsson F. Modeling the alkali sulfation chemistry of biomass and coal co-firing in oxy-fuel atmospheres. Energy \& Fuels 2014;28:3486-94.

[40] Tan Y, Jia L, Wu Y. Some combustion characteristics of biomass and coal cofiring under oxy-fuel conditions in a pilot-scale circulating fluidized combustor. Energy \& Fuels 2013;27:7000-7.

[41] Duan L, Duan Y, Zhao C, Anthony EJ. NO emission during co-firing coal and biomass in an oxy-fuel circulating fluidized bed combustor. Fuel 2015;150:8-13.

[42] Kosowska-Golachowska M, Wolski K, Kijo-Kleczkowska A, Musiał T, Środa K. Experimental research on oxy-fuel combustion of biomass in a circulating fluidized-bed. $7^{\text {th }}$ Eur. Combust. Meet. (ECM 2015), Budapest (Hungary): 2015.

[43] Sengeløv LW, Hansen TB, Bartolomé C, Wu H, Pedersen KH, Frandsen FJ, et 
al. Sulfation of condensed potassium chloride by $\mathrm{SO}_{2}$. Energy \& Fuels 2013;27:3283-9.

[44] Anthony EJ, Granatstein DJ. Sulfation phenomena in fluidized bed combustion systems. Prog Energy Combust Sci 2001;27:215-36.

[45] de Diego LF, de las Obras-Loscertales M, Rufas A, García-Labiano F, Gayán P, Abad A, et al. Pollutant emissions in a bubbling fluidized bed combustor working in oxy-fuel operating conditions: Effect of flue gas recirculation. Appl Energy 2013;102:860-7.

[46] Wu Y, Wang C, Tan Y, Jia L, Anthony EJ. Characterization of ashes from a 100 $\mathrm{kW}_{\text {th }}$ pilot-scale circulating fluidized bed with oxy-fuel combustion. Appl Energy 2011;88:2940-8.

[47] Jia L, Tan Y, Anthony EJ. Emissions of $\mathrm{SO}_{2}$ and $\mathrm{NO}_{\mathrm{x}}$ during oxy-fuel CFB combustion tests in a mini-circulating fluidized bed combustion reactor. Energy \& Fuels 2010;24:910-5.

[48] Valverde JM, Sánchez-Jiménez PE, Pérez-Maqueda LA. Limestone calcination nearby equilibrium: Kinetics, $\mathrm{CaO}$ crystal structure, sintering and reactivity. J Phys Chem C 2015;119:1623-41.

[49] Adánez J, De Diego LF, Gayán P, Armesto L, Cabanillas A. Modelling of sulfur retention in circulating fluidized bed combustors. Fuel 1996;75:262-70.

[50] Zijlma GJ, Jensen AD, Johnsson JE, van den Bleek CM. $\mathrm{NH}_{3}$ oxidation catalysed by calcined limestone-a kinetic study. Fuel 2002;81:1871-81.

[51] Zijlma GJ, Jensen AD, Johnsson JE, van den Bleek CM. $\mathrm{NH}_{3}$ oxidation catalyzed by partially sulphated limestone-modelling and experimental work. Fuel 2004;83:237-51.

[52] Zijlma GJ, Jensen A, Johnsson JE, van den Bleek CM. The influence of $\mathrm{H}_{2} \mathrm{O}$ and $\mathrm{CO}_{2}$ on the reactivity of limestone for the oxidation of $\mathrm{NH}_{3}$. Fuel 2000;79:1449-54.

[53] Liu H, Gibbs BM. The influence of calcined limestone on $\mathrm{NO}_{\mathrm{x}}$ and $\mathrm{N}_{2} \mathrm{O}$ emissions from char combustion in fluidized bed combustors. Fuel 2001;80:1211-5.

[54] Hansen PFB, Dam-Johansen K, Johnsson JE, Hulgaard T. Catalytic reduction on $\mathrm{NO}$ and $\mathrm{N}_{2} \mathrm{O}$ on limestone during sulfur capture under fluidized bed combustion conditions. Chem Eng Sci 1992;47:2419-24.

[55] Lupiáñez C, Díez LI, Romeo LM. NO emissions from anthracite oxy-firing in a 
fluidized-bed combustor: Effect of the temperature, limestone, and $\mathrm{O}_{2}$. Energy \& Fuels 2013;27:7619-27.

[56] Niu Y, Tan H, Hui S. Ash-related issues during biomass combustion: Alkaliinduced slagging, silicate melt-induced slagging (ash fusion), agglomeration, corrosion, ash utilization, and related countermeasures. Prog Energy Combust Sci 2016;52:1-61.

[57] Lupiáñez C, Mayoral MC, Guedea I, Espatolero S, Díez LI, Laguarta S, Andrés JM. Effect of co-firing on emissions and deposition during fluidized bed oxycombustion. Fuel 2016;184:261-68.

[58] García-Labiano F, Rufas A, de Diego LF, de las Obras-Loscertales M, Gayán P, Abad A, et al. Calcium-based sorbents behaviour during sulphation at oxy-fuel fluidised bed combustion conditions. Fuel 2011;90:3100-8.

[59] Laursen K, Duo W, Grace J., Lim J. Sulfation and reactivation characteristics of nine limestones. Fuel 2000;79:153-63.

[60] Shemwell B, Levendis YA, Simons GA. Laboratory study on the high-temperature capture of $\mathrm{HCl}$ gas by dry-injection of calcium-based sorbents. Chemosphere 2001;42:785-96.

[61] Partanen J, Backman P, Backman R, Hupa M. Absorption of $\mathrm{HCl}$ by limestone in hot flue gases. Part III: simultaneous absorption with SO. Fuel 2005;84:1685-94.

[62] Wang W, Li Y, Xie X, Sun R. Effect of the presence of $\mathrm{HCl}$ on cyclic $\mathrm{CO}_{2}$ capture of calcium-based sorbent in calcium looping process. Appl Energy 2014;125:246-53.

[63] Karlsson S, Pettersson J, Johansson L-G, Svensson J-E. Alkali induced high temperature corrosion of stainless steel: The influence of $\mathrm{NaCl}, \mathrm{KCl}$ and $\mathrm{CaCl}_{2}$. Oxid Met 2012;78:83-102. 